\title{
HIPERREALITAS DALAM SOCIAL MEDIA (STUDI KASUS: MAKAN CANTIK DI SENOPATI PADA MASYARAKAT PERKOTAAN)
}

\author{
Herlinda Fitria \\ Program S1 Sosiologi Universitas Indonesia \\ herlindafitria@gmail.com
}

\begin{abstract}
This study reviews the phenomenon of eating in restaurants that recently came out as a new lifestyle known as "makan cantik" (aesthetic eating). This lifestyle is currently trending among young people, especially those in the urban areas such as Jakarta. This study uses qualitative methods to observe and describe makan cantik as a hyperreality on social media, constructed through simulation. Makan cantik is done with an intention of broadcasting the activity through social media. Makan cantik is a simulation that is intentionally constructed to present certain image, such that represents the upper class society. Beneath what's been presented in social media, there is a contrasting condition of real life. Therefore, it can be said that there is no clarity of class status on social media, for social media nowadays is no longer presenting the reality, but instead the hyperreality.
\end{abstract}

\begin{abstract}
Abstrak
Penelitian ini akan mengkaji mengenai fenomena makan di restoran yang saat ini telah menjadi sebuah gaya hidup baru disebut sebagai makan cantik. Kegiatan tersebut sedang tren dilakukan anak muda khususnya yang tinggal di perkotaan seperti Jakarta. Penelitian ini menggunakan metode kualitatif untuk melihat dan menggambarkan makan cantik sebagai sebuah hiperealitas pada social media yang dibentuk melalui simulasi.Makan cantik dilakukan dalam rangka untuk memberitahukan kegiatannya kepada orang melalui social media. Makan cantik merupakan simulasi yang sengaja dibentuk untuk menampilkan image tertentu, karena hal tersebut dianggap dapat merepresentasikan masyarakat kelas atas. Di balik makan cantik yang di unggah di social media, ternyata hal tersebut berlainan dengan kondisi yang nyata. Sehingga dapat dikatakan bahwa telah terjadi pengaburan kelas dimana tidak adanya kejelasan dari status kelas yang dimunculkan di social media. Social media saat ini tidak lagi menampilkan realitas yang sebenarnya, namun menampilkan hiperrealitas.
\end{abstract}

Keywords: Hyperreality, Simulation, Makan Cantik 


\section{PENDAHULUAN}

Makan adalah kebutuhan utama yang harus dipenuhi untuk memenuhi kebutuhan lanjutan lainnya (Maslow, 1989). Makanan pada umumnya merupakan bagian dari per-tahanan hidup manusia. Makanan saat ini mempunyai arti berbeda dari sekedar asupan makan untuk pertahanan hidup. Makanan telah menjadi bagian penting dari gaya hidup. Hasil riset yang dilakukan oleh Qraved.com--merupakan aplikasi kuliner berbasis online. Aplikasi ini dapat digunakan untuk melakukan reservasi restoran. Qraved. com menyediakan list berbagai restoran di Jabodetabek dan Bali, jenis makanan, menu makanan dan minuman, harga, alamat dan jadwal buka dan tutup restoran-menunjukan telah terjadi pergerseran tren. Semakin banyak masyarakat Indonesia yang memiliki kebiasaan makan di restoran. Hal ini merupakan salah satu fenomena baru yang terjadi khususnya pada masyarakat perkotaan.

Hasil survei Nielsen Indonesia (2009) pada 894 responden dari 6 kota besar di Indonesia (Jakarta, Bandung, Surabaya, Semarang, Makassar dan Medan) menunjukkan 44\% dari responden suka makan diluar rumah pada malam hari dengan frekuensi 1-3 kali perbulan. Dari survey tersebut juga diperoleh hasil bahwa kegiatan makan tidak hanya sekedar untuk memenuhi kebutuhan akan makanan namun lebih kepada sosialisasi. Selain itu, survey yang dilakukan Jakarta Dining Index (2013) menyebutkan kunjungan orang Jakarta ke restoran sepanjang 2013 mencapai 380 juta kali dan menghabiskan total Rp. 17 triliun pertahunnya.

Pembahasan mengenai kegiatan makan di masyarakat telah banyak dikaji di berbagi Negara. Penelitian yang dilakukan oleh Murcott pada 1988 menyebutkan bahwa kegiatan makan bukan hanya suatu kegiatan untuk memenuhi kebutuhan jasmaniah tetapi juga untuk mencerminkan diri secara sosial yang berhubungan langsung dengan status, kesejahteraan dan pekerjaan tertentu (Murcott, Anne. 1988: 5-15). Bergeser ke periode tahun selanjutnya Djaafara pada 1994 menyebutkan bahwa fungsi kegiatan makan bagi para pekerja adalah untuk menunjang pekerjaan dimana kegiatan makan digunakan sebagai media kegiatan interaksi (relasi sosial) dengan sesama pekerja dan atasan (Djafaara, Febiana. 1994: 125).

Kemudian menurut Meliono dan Budianto dominasi kebudayaan manusia menjadi sangat berperan terutama dalam pola makannya. Makanan terkategorisasi menjadi makanan yang boleh dimakan dan tidak boleh dimakan (Meliono dan Budianto, 2004: 70). Penelitan yang dilakukan oleh Murwani pada 2014 menyimpulkan bahwa makan diluar dipengaruhi oleh internal forces yang terjadi melalui relasi-relasi kuasa dalam struktur masyarakat yang membentuk tentang habitus suatu makanan (Murwani, Endah. 2014: 312).

Sedangkan menurut Raditya makanan yang estetik menciptakan sebuah pola baru dalam pengklasifikasian kelas dimana merekayang mengkonsumsi makanan estetik akan dianggap sebagai orang yang berkelas (Raditya, Michael HB. 2014: 158). Berpijak pada tahun 1988 sampai dengan tahun zoooan, makanan sudah menjadi bagian dari gaya hidup yang berhubungan dengan relasi sosial. Hal berbeda terjadi pada periode tahun 2014 dimana social media memiliki peranan penting dalam pembentukan tren makan saat ini.

Makan di restoran dilakukan bukan dalam rangka untuk makan namun lebih kepada menyiar-nyiarkan hal tersebut di social media. Kondisi ini dialami oleh masyarakat kota-kota besar salah satunya Kota Jakarta. Masyarakat kota Jakarta saat ini gemar melakukan kegiatan makan di restoran dan mengunggah kegiatannya di social media, yang mereka sebut sebagai makan cantik.

Makan cantik merupakan sebuah konsep yang dibuat oleh masyarakat kelas tertentu di Jakarta. Salah satu daerah di Jakarta sebagai tempat terbentuknya konsep tersebut adalah wilayah Senopati. Masyarakat kota yang makan cantik di daerah Senopati menyebar luaskan kegiatannya melalui social media. Makan cantik yang diunggah di dalam social media merupakan suatu hal yang berbeda 
dari fakta yang ada. Terdapat perbedaan kondisi pelaku pada apa yang diunggah dengan kondisi yang nyata. Dalam hal ini masyarakat melakukan apa yang disebut oleh Baudrillard sebagai simulasi.

\section{METODE}

Di dalam sebuah penelitian dibutuhkan satu metode yang paling tepat untuk bisa mendapatkan data yang valid. Metode Penelitian yang banyak digunakan adalah metode penelitian secara kuantitatif dan kualitatif. Penelitian ini menggunakan pendekatan kualitatif agar mendapatkan data yang lebih mendalam terhadap subjek penelitian di mana peneliti menjadi instrument itu sendiri. Peneliti menggunakan metode kualitatif untuk menggambarkan makan cantik sebagai hiperealita pada social media. Penelitian kualitatif menurut Lincoln dalam Neuman (2003: 72) adalah penelitian yang menekankan pada proses dan pemaknaan atas realitas sosial yang tidak diuji atau diukur secara ketat dari segi kuantitas, ataupun frekuensi.

Fokus dari penelitian kualitatif adalah menjelaskanbagaimanagejalasosialdibentuk dan diberi makna. Penelitian ini merupakan penelitian cross-sectional research dimana penelitian ini hanya dilihat dari kurun waktu tertentu saja. Karena penelitian ini dilakukan selama 2 bulan terhitung selama bulan Oktober dan November 2015. Terdapat dua jenis data yang digunakan dalam penelitian ini, yaitu data primer dan data sekunder.

Data Primer diperoleh dengan melakukan wawancara mendalam dengan 3 orang informan. Informan penelitian dipilih dengan kriteria makan di restoran dan mengunggah kegiatannya di social media. juga pada saat itu sedang berada di restoran Senopati. Informan pertama, berinisial MT ia merupakan seorang mahasiswa yang rutin makan di restoran setiap weekend. Informan kedua, berinisial B merupakan seorang karyawan swasta yang memiliki hobi makan di restoran. Dan informan GO merupakan pegawai di sebuah instansi perpajakan.

Wawancara dengan tiga orang infor- man dilakukan secara langsung di sebuah restoran di Senopati. Selain wawancara, data sekunder diperoleh dari jurnal, literature, buku, data publikasi serta observasi tidak langsung melalui media elektronik dan media cetak. Logika berpikir dalam penelitian ini merupakan logika induktif, yaitu dalam membangun sebuah kesimpulan yang bersifat umum dari hal hal yang khusus pada temuan data di level empirik.

\section{HASIL DAN PEMBAHASAN}

\section{Hiperrealitas}

Berbagai tulisan Baudrillard mengandung ciri dari teori postmodern. Empat istilah kunci yang mendasari analisisnya adalah simulasi, mediamassa, tandadan komunikasi. Namun penelitian ini hanya membahas satu pembahasan saja mengenai simulasi yang berarti citra, simbol, gambar buatan, atau segala hal yang "menyembunyikan" kenyataan (Baudrillard 1981). Dalam bukunya Simulations, Simulasi bukan menutupi kenyataan, namun kenyataan yang menutupi ketiadaan. Sehingga dapat dikatakan simulasi adalah nyata.

Terdapat Empat citra dari penampilan yang telah membentuk kultur Barat antara lain realistic yaitu keadaan sebenarnya, counterfeit yakni tahap alami yang dapat ditemukan lewat imitasi, production yaitu tahap produksi dan simulation yang merupakan simulacra dari simulasi, pembuatan informasi dan kode. Citra satu sampai tiga merupakan sebuah citra yang sudah terjadi pada tahun-tahun sebelumnya. Sedangkan citra ke empat yaitu simulasi menggambarkan kehidupan masyarakat saat ini. Simulasi berarti bahwa citra tidak terkait dengan kenyataan apapun (Baudrillard 1983).

Simulasi tidak hanya berkaitan dengan tanda, namun juga menyangkut kekuasaan dan relasi sosial, dimana yang berlaku adalah tanda murni yang kehilangan referensinya. Simulasi dan kode seluruh realitas menuju hiperealitas dimana tidak ada lagi distingsi antara realitas dengan khayalan, antara hasil kopian dengan realitas aslinya, dan dimana 
realitas diuapkan menuju kelenyapan (Baudrillard, 1983 dalam Kushendrawati, 2006: 131). Sehingga dapat disimpulkan bahwa tidak ada lagi realitas dasar yang diacu oleh objek dan tanda-tanda. Ini adalah era hiperrealitas. Disneyland adalah model sempurna dari bagaimana masing-masing orde saling berkaitan. Di sana ada perompak, frontir, dunia masa depan, kastil-kastil, dunia robot. Sebuah dunia buatan di mana semua nilai dimuliakan, disimulasikan, dan dihadirkan kepada pemirsa (Baudrillard 1983 dalam Denzin, 1986).

\section{Makan Cantik di Senopati}

Makan cantik merupakan sebuah kata untuk menggambarkan kegiatan makan yang dilakukandirestoran-restoran tertentudalam rangka untuk menyiar-nyiarkan kegiatannya ke dalam social media. Masyarakat kota saat ini banyak memilih makan di restoran untuk mengisi leisure time yang mereka miliki. Makan cantik bukanlah kegiatan makan yang dilakukan3kaliseharisepertipadaumumnya. Namun makan cantik biasanya dilakukan 2 sampai 3 kali setiap bulannya. Hal yang pertama-tama dilakukan masyarakat dalam melakukan makan cantik adalah pemilihan restoran. Pemilihan restoran menjadi hal yang paling penting untuk melakukan aktifitas ini. Karena pemilihan restoranlah yang akan menentukan apakah hal tersebut masuk kedalam kategori makan cantik atau tidak.

Makan cantik biasanya dilakukan di restoran-restoran kelas menengah dan atas. Berbagai aspek menjadi pertimbangan masyarakat dalam memilih restoran, antara lain dekorasi atau design interior ruangan, penyajian makanan dan lokasi restoran. Namun yang menarik adalah rasa dari makanan yang seharusnya menjadi pertimbangan seseorang untuk memilih restoran, kini tidak terlalu menjadi perhatian bahkan dibuang sama sekali. Menurut informan MT,

"Pertama gue liat dari ambiance nya dulu. Ambiance tuh kaya mulai dari design interiornya, panas apa engga tempatnya. Jadi gueliat tempatnya dulu.
Terus gue liat dari plating makanannya, apakah penyajianya menarik apa engga soalnya percuma nih gue udah ketempat mahal tapi ga bagus duit gue sayang. Kaya kemaren tuh saya makan tuna salad, itu ga kenyang sih tapi bagus banget buat di foto. Padahal tuna juga gue beli dipasar juga cuma 2oribu. Nah itu harganya 15orb".

(Wawancara dengan MT, 27 Oktober 2015)

Berdasarkan penuturan informan diatas, makanan yang dipesan tidak terlalu penting untuk di pertimbangkan. Menurutnya, design interior dan penyajian makanannya lah yang paling diutamakan dalam makan cantik. Hal ini dikarenakan pelaku makan cantik membutuhkan dekorasi yang sekiranya menarik untuk berfoto. Karena kunci dari makan cantik itu sendiri adalah mengunggah kegiatannya dengan semenarik mungkin di social media yang mereka miliki. Menarik dalam artian apa yang di unggah akan membuat orang lain merasa tertarik untuk datang ke restoran tersebut.

Hal penting yang kedua adalah penyajian makanan. Sama halnya dengan design interior restoran, makan cantik juga sangat membutuhkan penyajian makanan yang menarik dan unik. Karena pelaku akan mengabadikan gambar makanan tersebut untuk di unggah ke dalam social media. Oleh sebab itu, penyajian makanan ditata sedemikian rupa agar menarik perhatian orang lain dianggap penting. Tidak menjadi permasalahan jika makanan yang disediakan kurang enak, karena bukan hal tersebut yang diutamakan. Pelaku makan cantik cenderung menutupikekurangandarimakanantersebut. Salah satunya dengan cara mengambil beberapa sisi dari makanan agar terlihat menarik. Selain itu pelaku juga tidak akan berkeluh kesahatau menampilkan kesanyang jelek tentang makanan yang dipesan. Justru pelaku seolah-olah sedang mempromosikan restoran yang sedang ia kunjungi, sekalipun hal itu tidak mendapat reward apa-apa dari restoran yang bersangkutan. 
Dan hal penting yang ketiga adalah lokasi restoran. Lokasi-lokasi restoran tertentu menjadi sorotan para pelaku untuk menambah pengalaman makannya di berbagai restoran yang ada. Di Jakarta sendiri wilayah-wilayah yang menjadi highlight untuk melakukan makan cantik seperti Senopati, Kemang, Thamrin. Ketiga wilayah tersebut merupakan lokasi favorit para pelaku makan cantik untuk berburu restoran yang dianggap dapat mewakili kelas sosial tertentu. Namun yang lokasinya paling strategis dan berada di tengah kota adalah Senopati. Tidak hanya itu, wilayah ini banyak berdiri restoran dengan berbagai macam jenis restoran, mulai dari masakan Indonesia, Western, Korean, Japanese, dan lain-lainnya tersedia di wilayah ini.

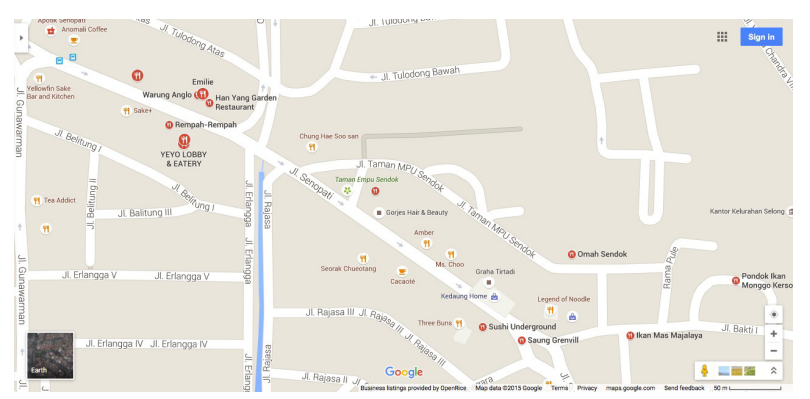

Gambar 1.1 Map Lokasi Restoran di Senopati Sumber: Google Maps

Gambar diatas menunjukan gambaran wilayah Senopati. Secara geografis lokasi Jl. Senopati dan Gunawarman berada pada jalan yangberbeda. NamunSenopatiyangadadalam pikiran masyarakat adalah Senopati secara keseluruhan yang mencakup Jl. Senopati, Jl. Gunawarman, Jl. Rajasa, Jl. Belitung dan jalan-jalan lain yang ada di sekelilingnya. Hal ini diperkuat dengan pernyataan informan MT, menurutnya Senopati itu bukan hanya dilihat dari sepanjang Jalan Senopati itu saja, namun daerah disekelilingnya dianggap masih termasuk daerah Senopati. Letak dari satu restoran ke restoran lainnya di Senopati sangat berdekatan. Banyak anggapan bahwa wilayah ini merupakan lokasi yang tepat untuk berburu kuliner yang berbeda dari yang lain.

Di Senopati, restoran yang menjual jenis makanan Western paling banyak di gemari dan jumlahnya pun memiliki proporsi terbanyak dari jenis makanan lain diluar makanan Indonesia. Dari hasil wawancara ketiga informan, mereka lebih sering mencoba restoran-restoran yang menyediakan makanan western. Hasil observasi yang dilakukan peneliti menyebutkan bahwa terdapat 17 restoran Western di Senopati. Jumlahnya paling banyak bila dibandingkan dengan Korean Restaurant, Chinese Restaurant, dan jenis restoran lainnya. Restoran yang ada di Jalan Senopati ini biasanya akan ramai di hari-hari tertentu seperti pada hari Sabtu dan Minggu. Karena kegiatan ini biasanya dilakukan untuk mengisi waktu luang. Dan memang kebanyakan masyarakat yang makan di lokasi ini adalah mahasiswa, karyawan muda dan hanya sedikit sekali orang tua (Hasil observasi langsung di beberapa restoran di Senopati).

Pemilihan restoranyang akan dikunjungi untuk melakukan makan cantik mengalami proses yang cukup panjang. Para pelaku makan cantik juga menjadikan social media sebagai acuan dalam pemilihan restoran. Platform kuliner berbasis aplikasi seperti Zomato dan Qraved menjadi acuan dalam memilih restoran. Sebab kedua aplikasi tersebut menampilkan informasi yang sangat lengkap tentang kuliner seperti menu dan harga, peta lokasi, bahkan pelaku bisa mengetahui restoran lebih lengkap lewat foto-foto yang tersedia di aplikasi tersebut. Kedua aplikasi ini tidak hanya menampilkan informasi mengenai restoran namun juga merekomendasikan restoran-restoran sesuai dengan keinginan masyarakat. 


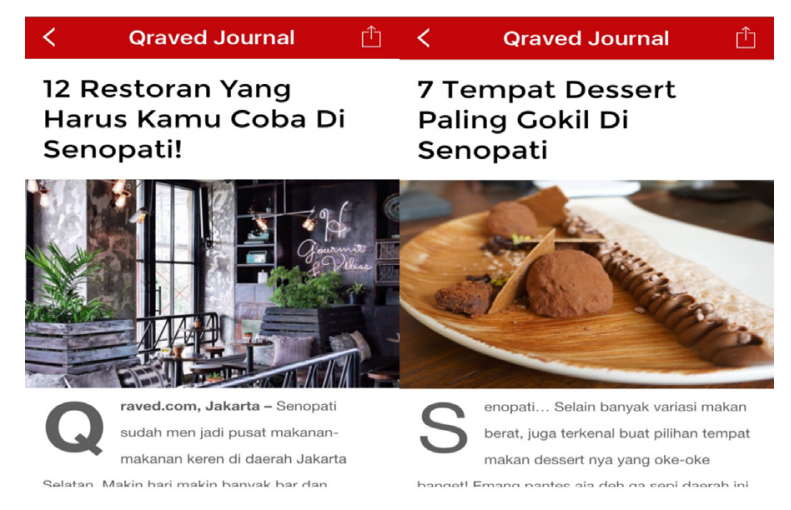

Gambar 1.3 Laman Aplikasi Qraved

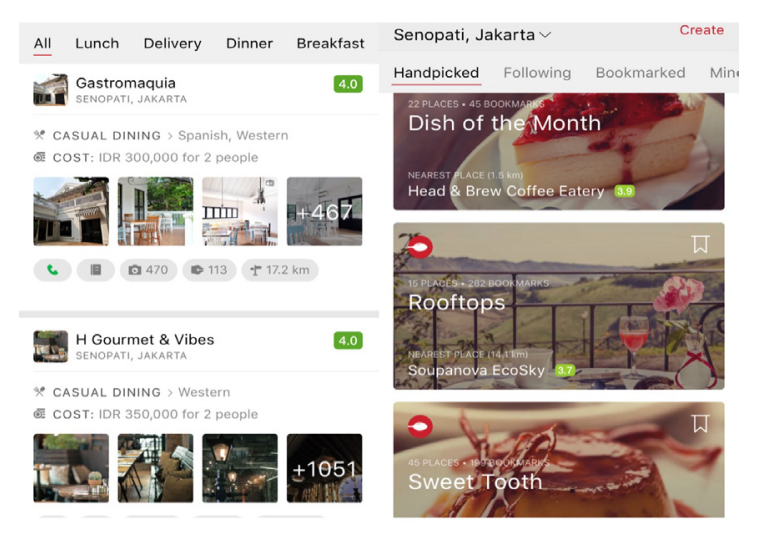

\section{Gambar 1.2 Laman Aplikasi Zomato}

Gambar diatas merupakan beberapa tampilan dalam aplikasi Zomato dan Path. Pengguna aplikasi tersebut dapat dengan mudah melihat berbagai restoran yang ada di Jakarta. Pengguna juga dapat men sortir restoran yang dimaksud, mulai dari lokasi, jenis makanan yang dijual dan lain-lain. Pengguna juga bisa mengetahui perihal restoran secara lengkap, seperti harga, makanan, minuman, jam buka dan lain sebagainya. Oleh sebab itu aplikasi ini sedikit banyak mempengaruhi pelaku makan cantik dalam pemilihan restoran.

Selaindariaplikasikulinerberbasisonline diatas, status yang diunggah oleh orang lain di social media juga menjadi pertimbangan pemilihan restoran untuk makan cantik. Semakin banyak orang yang mengunggah keberadaannya di restoran tersebut, akan menambah rasa ingin tahu orang lain terhadap restoran tersebut. Sehingga secara tidak langsung apa yang orang lain unggah di social media mempengaruhi pemilihan restoran yang akan dikunjungi.

Setelah tahap pemilihan selesai selanjutnya masuk kedalam kegiatan inti yaitu makan cantik. Sesampainya di restoran pelaku memesan makanan seperti makan di restoran pada umumnya. Namun ada hal yang membedakan dengan makan cantik dan makan biasa di restoran. Setelah makanan yang dipesan datang, pelaku makan cantik tidak langsung memakan makanan yang dipesan. Pelaku terlebih dahulu memotret makanan tersebut dari berbagai sisi. Tentunya tidak hanya di potret satu kali saja, namun berkali-kali sampai pelaku mendapatkan hasil yang terbaik. Baik dalam hal ini adalah menarik, unik dan membuat orang tertarik untuk datang ke restoran tersebut.

Sering kali makanan yang dipesan tidaklah sesuai dengan selera lidah mereka. Namun makanan tersebut dipesan karena makanan tersebut menarik secara estetika. Pelaku memilih makanan yang penyajiannya menarik dan unik karena pelaku membutuhkan hal tersebut untuk difoto dan diunggah di social media. Apapun makanannya walaupun tidak enak ataupun porsinya sedikit, asalkan penampilannya menarik pelaku akan memesan makanan tersebut.

Setelah selesai memotret makanan, ada 1 hal lagi yang biasa dilakukan oleh pelaku makancantikyaitumemotretinteriorruangan. Hal ini dilakukan untuk memberitahukan kepada orang banyak bahwa pelaku saat ini sedang makan ditempat yang unik. Memotret interior ruangan bisa dilakukan dengan dua opsi. Opsi yang pertama adalah memotret interior ruangannya saja. Atau opsi kedua adalah memotret dirinya sendiri, karna dengan memotret dirinya sendiri secara tidak langsung akan menampilkan interior ruangan secara bersamaan.

Kemudian setelah menyantap makanan, pelaku makan cantik tidak langsung meyudahi kegiatannya kemudian pulang. Disinilah inti dari kegiatan ini, yaitu memberitahukan kegiatan makannya di 
social media yang mereka miliki. Social media yang menjadi platform pelaku untuk mengunggah statusnya antara lain adalah Path, Instagram, dan berbagi social media lainnya. Begitu juga yang dilakukan informan GO yang menjelaskan hal-hal yang di posting didalam akun social media nya,

"Biasanya gue nunjukin tuh location gue dimana. Soalnya itu yang paling penting ya jadi percuma ya kalo update di suatu tempat tapi ga keliatan tempatnya tuh jadi gue bisa nunjukin gue ada dimana. Karena kan yang menjual dari makan cantik itu kan lokasinya kan. Nah itu satu. Yang kedua mungkin gue update pake foto sih biasanya. Jadi ini loh restoran yang mahal, ini loh restoran yang lagi inn, ini loh makan cantik gue. Kaya gitu sih."

(Wawancara dengan GO, 8 November 2016)

Pernyataan informan diatas menjelaskan status yang diunggah di akun social media yang ia gunakan. Ia menggunakan berbagai fitur-fitur yang ada di social media untuk menunjukan kegiatannya. Namun yang paling utama untuk diposting di social media adalah foto. Pelaku makan cantik juga menghabiskan waktunya berjam-jam untuk sekedar bermain gadget. Tak heran bahwa setiap restoran yang ada selalu menyediakan wifi sebagai fasilitasnya, sehingga pelaku betah untuk berlama-lama direstoran tersebut. Karena kegiatan makan cantik merupakan kegiatan yang tidak terlepas dari gadget sehingga dibutuhkan listrik untuk dapat menunjang kegiatan ini. Oleh sebab itu tak jarang pelaku makan cantik terlebih dahulu menanyakan 'colokan' (listrik) kepada pelayan restoran sebelum memesan makanan.

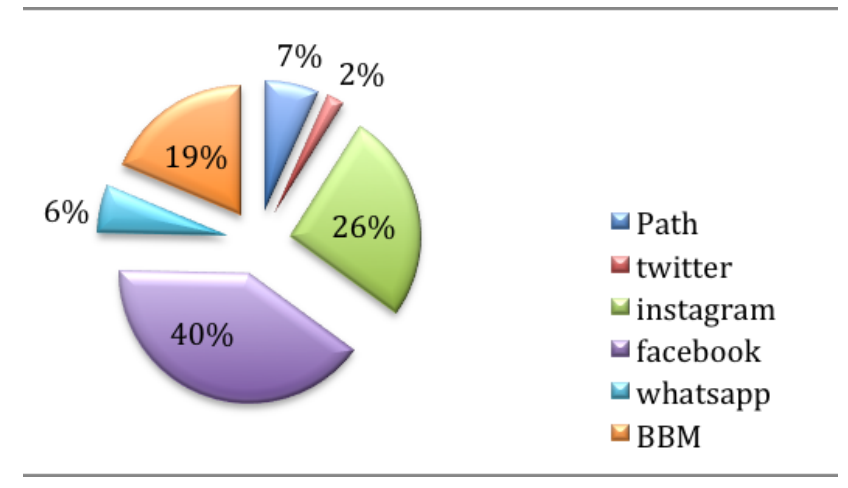

\section{Tabel. 1.1 Media Sosial Utama dalam Mengunggah Foto Makanan Sumber: Kompas.com}

Data di atas menunjukan bahwa masyarakat saat ini menggunakan berbagai platform social media seperti, Facebook, Instagram, Twitter, Path dan lain sebagainya. Namun data yang didapat dari ketiga informan, mereka menggunakan platform Path dan Instagram saja. Menurutnya penggunaan social media lainnya diluar Path dan Instagram tidak mewakili kelas sosial atas. Pemilihan platform Path untuk memberitahukan kegiatannya juga dilatar belakangi karena path memiliki fitur yang dapat menujukan keberadaan pelaku saat ini. Didalam path terdapat fitur-fitur yang memungkinkan kita untuk memposting foto, lokasi, lagu, dan lain-lainnya. Sehingga pelaku bisa memposting foto bersaman dengan lokasi dan caption apa yang ingin diberitahukan. Namun dalam kasus makan cantik hal yang biasa diunggah oleh pelaku adalah berupa foto makanan ataupun foto dirinya yang sedang berada di restoran tersebut. 


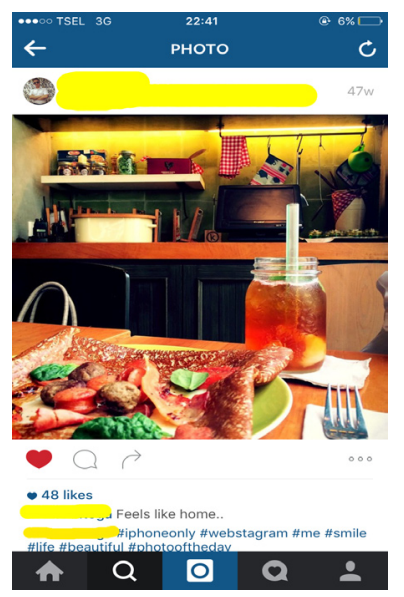

Gambar 1.5 Seorang informan BS mengunggah staus makannya di Instagram

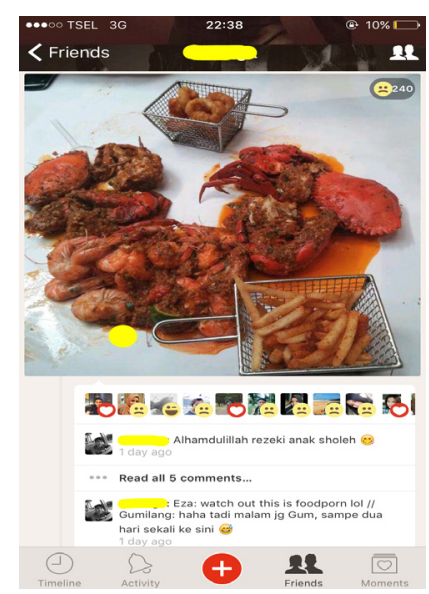

Gambar 1.4 Seorang informan MT mengunggah status makannya di media sosial Path

Gambar 1.4 merupakan foto makanan yang ada pada restoran The Holy Crab. Pelaku sengaja memotret kepiting tersebut lebih dekat agar kepiting tersebut terlihat lebih besar dan menarik. Selain itu penyajian yang tidak lazim membuat foto ini sangat menarik karna tidak menggunakan piring. Sehingga orang lain akan tergugah untuk mencoba makanan tersebut. Sedangkan untuk gambar 1.5 pelaku memotret foto makanan beserta interior ruangan sehingga menjadi sangat menarik dan terlihat sangat unik. Pelaku makan cantik selalu berusaha mengambil sisi yang paling menarik dari sebuah makanan agar tidak terlihat biasa. Social media memiliki peranan yang paling penting dalam kegiatan ini sebab makan cantik tidak bisa disebut sebagai makan cantik ketika pelaku tidak menyebar luaskan kegiatan yang mereka lakukan di sosial media.

\section{Makan Cantik sebagai Hiperrealitas dalam Sosial Media}

Makan cantik telah menjadi bagian dari gaya hidup masyarakatperkotaan. Gayahidup sering dihubungkan dengan kelas sosial ekonomi dan citra yang dimiliki seseorang. Makan cantik sebagai gaya hidup ditunjukan dalam keputusan pemilihan restoran yang dikunjungi dan makanan yang disantap. Hal tersebut dianggap dapat merepresentasikan kelas sosial seseorang. Gaya hidup yang ditunjukan dalam makan cantik adalah makan direstoran yang dilengkapi dengan interior ruangan yang mewah ataupun menarik, penyajian makanan yang menarik dan penggunaan pakaian yang rapih ataupun semi formal. Sehingga hal tersebut dapat membentuk citra masyarakat kelas atas.

Masyarakat kota merupakan masyarakat yang dibanjiri oleh citra dan informasi, membuat simulasi dan citra menjadi suatu hal yang paling diminati dan diperhatikan dalam kebudayaan masyarakat pascamodern. Di sinilah kenyataan diproduksi oleh simulasi berdasarkan model-model (yang tidak memiliki asal-usul atau referensi realitas) dan secara artifisial direproduksi sebagai kenyataan (Baker, Chris. 2011: 166 dalam Alfian. 2014).

Fenomena menarik terkait dengan hal yang dibayangkan dalam pikiran mendahului realitas adalah makan cantik, secara tidak langsung memberikan suguhan tentang penggambaran makan yang dilakukan oleh orang yang berada pada kelas sosial atas. Makan seharusnya hanya menjadi representasi dari kehidupan nyata, namun saat ini telah menjadi realitas sendiri. Makan cantik yang diunggah di social media telah menggantikan posisi pada ruang nyata atau rill yang menjadi sumber utama reproduksi. Baudrillard menyebut fenomena ini sebagai hiperrealitas dimana suatu hal berkembang 
dengan sendirinya membentuk realita baru yang penuh dengan rekayasa.

Makan cantik merupakan sebuah kegiatan yang dilakukan dengan maksud dan tujuan tertentu. Masyarakat kota saat ini sedang berlomba-lomba untuk melakukan makan cantik, sebab kegiatan ini dianggap memiliki nilai-nilai tambahan dari sekedar makan. Makan cantik dan social media merupakan satu kesatuan yang utuh karena tidak bisa disebut sebagai makan cantik jika hal tersebut tidak di siar-siarkan di social media. Social media menjadi ruang terbaik hiperrealitas, karena social media dapat merepresentasikan hiperrealitas menjadi realitas palsu. Makan cantik yang di siar-siarkan di social media merupakan simulasi yang menayangkan kondisi realitas kehidupan. Dalam hal ini makan cantik yang di unggah di social media sudah tidak lagi berfungsi seperti fungsi sebenarnya.

Social media merupakan arena sosial dalam rangka memberitahukan kegiatan tersebut, yang tidak semata-mata untuk menunjukan bahwa ia makan. Jika dipahami secara lebih mendalam sebenarnya makan cantik merupakan praktek untuk menunjukan kemampuan finansial, kelas ataupun eksistensi diri. Menurut informan MT,

"Gue makan cantik gara-gara awalnya mungkin gue penasaran sama bentuknya. Kaya misalnya gue liat dari update an orang difoto disitu bagus. Trus kalo gue makan di tempat kaya gitu ya secara ga langsung sih pengen nunjukin yang namanya status sosial, kaya gitu. Ya kita juga ngeluarin duit segitu juga bukan buat ya... misalnya ada makna lah dibalik itu. Jadi ya antara 2 itu either ya gue pengen update ke orang tapi kalo misalnya ga pengen update ya engga. Yang gue tunjukin itu tadi, ya mungkin gue juga bisa berbagi ke orang kalo misalnya platingnya bagus atau apanya bagus."

(Wawancara dengan MT, 27 Oktober 2015)

Berdasarkan penuturan informan tersebut dapat terlihat bahwa dengan makan cantik maka pamor dan gengsinya pada tataran sosial secara otomatis akan naik. Artinya dengan makan di restoran sebenarnya ia sedang menunjukan sesuatu dengan kegiatan tersebut. Kemudian ia juga ingin memperlihatkan kemampuannnya pada orang lain, baik kepada sesama pelaku makan cantik maupun tidak. Dengan cara ini, secara sengaja pelaku ingin memperlihatkan siapa dirinya, kemampuan ekonominya atau kelasnya.

Kemudian dengan makan cantik di restoran, pelaku ingin memperlihatkan kelas sosialnya dengan berusaha mencari restoranrestoran yang sedang ramai di perbincangkan atau restoran unik yang baru saja dibuka. Hal ini tentunya memiliki arti bahwa pelaku selalu ingin mengikuti mode walaupun dengan berbagai konsekuensi yang harus dipenuhi, tak terkecuali mengeluarkan biaya yang tidak sedikit.

Menurut informan GO, biaya yang harus dikeluarkan untuk sekali makan berdua adalah Rp.200.ooo. Bahkan menurut informan BS ia menghabiskan Rp.350.00o sampai dengan Rp.2.00o.ooo untuk satu kali makan di restoran. Informan BS juga menyebutkan bahwa ia pernah datang di berbagi restoran yang ada di Senopati, sekalipun makanan yang dijual relatif sama. Dengan datang ke banyak restoran orang lain akan menganggap bahwa pelaku memiliki kemampuan ekonomi yang tinggi dan secara tidak langsung gengsinya pun akan naik.

Secara tidak langsung dapat dikatakan bahwa seseorang yang melakukan aktifitas makan cantik mempunya finansial yang kuat sehingga dapat dikategorikan sebagai kelas sosial atas. Peran dari social media lah yang kemudian memunculkan kesan siapa orang tersebutdari kegiatanyangdilakukan. Mereka yang melakukan makan cantik dianggap sebagai orang yang berkelas. Sedangkan mereka yang tidak akan dianggap sebaliknya. Hal ini tentunya sudah terkonstruksi di dalam pikiran masyarakat dan telah menjadi gaya hidup baru khususnya pada masyarakat perkotaan.

Makan cantik merupakan representasi kelas atas yang difasilitasi oleh social media 
sebagai pembentuk indentitas. Makan cantik menjadi sebuah gambaran atau citra yang melambangkan eksistensi dan kelas sosial masyarakat. Sehingga "Apa yang dimakan", "Dimana memakannya?", Kapan memakannya?", Bagaimana cara memakannya?", menjadi sebuah simbol dari kelas sosial baru yang memperlihatkan "siapa Anda?". Makan cantik secara tidak langsung dikonstruksi oleh individu lewat social media, namun dalam perjalannya, makan cantik sebagai suatu hal yang dikonstruksi ternyata dapat mengkonstruksi orang lain. Sehingga menjadikan orang lain juga terpengaruh untuk melakukan makan cantik dari apa yang di posting pelaku makan cantik di social media. Hal ini dirasakan oleh informan $\mathrm{GO}$ yang menyatakan,

"Gue juga tau restoran-restoran gitu dari update-an temen gue di path dan gue malah ngerasa sekarang gue jadi trendsetter. Jadi kaya misalnya gue berkunjung kesuatu tempat terus makin banyak aja orang yang kesana. Gue punya pengaruh buat orang lain dan secara ga langsung gue juga dipengaruhi orang lain."

(Wawancara dengan GO, 8 November 2015)

Informan GO menyadari bahwa dalam hal ini ada konstruksi-konstruksi yang dilakukan oleh social media, yang juga secara tidak langsung dirinya pun ikut mengkonstruksi makan cantik tersebut. Dan hal tersebut diakui oleh informan GO merupakan salah satu tujuannya dalam melakukan makan cantik. Makan cantik merupakan kegiatan yang tidak murah dan tidak semua orang bisa melakukannya. Hanya beberapa kalangan saja yang bisa menikmati pengalaman makan diberbagai restoran. Hal ini dikarenakan harga makanan yang dijual di restoran-restoran tersebut diatas Rp.50.ooo untuk satu menu makanan ataupun minuman. Sehingga orang-orang yang tidak memiliki kemampuan finansial yang cukup tidak dapat melakukan kegiatan ini.
Namun hal ini tidak berlaku bagi sebagian orang, dimana makan cantik merupakan ritual yang rutin harus dilakukan. Walaupun dengan berbagai kendala yang dihadapi, terutama permasalahan finansial. Pelaku makan cantik memerlukan biaya yang tidak sedikit untuk bisa makan di restoran-restoran cantik ini. Namun hal tersebut tak menghalangi niat pelaku untuk makan cantik. Berbagai usaha dilakukan agar hal tersebut dapat terwujud, salah satunya dengan menyisihkan uang agar makan cantik di akhir minggu dapat terpenuhi. Seperti yang dikatakan oleh informan MT, bahwa

"Kalo soal rasa sih kebetulan gue ga peduli sama rasa. Kadang kalo makanannya dikit tp enak udah nggapapa walaupun gue ga kenyang. Gue bakal Menuhin kekenyangan gue nanti ditempat lain yang ga mewah itu. Misalnya gue makan di hotel mulia makan salad gitu. Ujung-ujungnya gue bakal makan nasi goreng dipinggir jalan sampe kenyang".

(Wawancara dengan MT, 27 Oktober 2015)

Cara lain diungkapkan oleh informan GO agar makan cantik dapat terealisasi,

"Kalo dari apa yang gue lakuin mungkin iya. Karna gueyakin orang-orang ngeliat gue ih Bella makan ke tempat mahal mulu, Bella tajir ya, Bella hedon banget makan ke tempat-tempat cantik mulu. Tapi kan pada kenyataannya gue ga makan kan disana, gue cuma minum, gue cuma beli sesuatu yang murah lah disana. Padahal kan sebelum dateng kesitu gue makan pecel lele dipinggir jalan dulu. Jadi Rahasianya itu, sebelum ketempat yang mewah yang kaya Senopati yang makanannya mahal padahal sebenernya sih gue minum doang."

(Wawancara dengan GO, 8 November 2015)

Hal di atas menunjukan bahwa pelaku makan cantik telah memanipulasi siapa 
dirinya. Saat sedang melakukan makan cantik ia menyiar-nyiarkan kegiatannya di dalam sosial media. Sedangkan saat makan di warteg atau warung pinggir jalan hal tersebut tidak diberitahukan kedalam arena sosial. Sehingga memunculkan pertanyaan mengapa hanya makan cantiknya saja yang diunggah namun yang makan di warung dipinggir jalan tidak? Ada hal yang ingin dibentuk oleh pelaku agar membentuk pandangan tertentu didalam masyarakat terhadap dirinya.

Sosial media dalam hal ini merupakan tempat terjadinya proses simulasi berlangsung. Manusia didalam pascamodern ini menjadikan sosial media sebagai acuan dari kehidupan nyata. Sehingga apa yang ada pada social media dianggap sebagai hal yang nyata. Namun sebenarnya makan cantik yang diunggah di dalam social media merupakan suatu hal yang berbeda dari fakta yang ada. Terdapat perbedaan kondisi pelaku pada apa yang diunggah dengan kondisi yang nyata. Dalam kondisi nyata pelaku bukanlah mereka yang berasal dari golongan atas, pelaku berasal dari kelas bawah maupun menengah yang mencoba menunjukan kelas yang sebenarnya bukan bagian dari dirinya.

Pelaku makan cantik tidak selalu mengeluarkan uang yang besar dalam makan cantik. Karena beberapa dari mereka hanya memesan minuman saja ataupun makanan yang harganya murah. Terkadang mereka memesan air mineral atau es teh manis saja di sebuah restoran. Namun berlama-lama menikmati keindahan restoran tersebut dan mengunggah foto seolah-olah mereka memang sedang makan-makan di sana. Dalam hal ini masyarakat melakukan apa yang disebut oleh Baudrillard sebagai simulasi.

Lalu dari kedua hal tersebut antara makan direstoran dan makan-makan di tempat rumah makan pinggir jalan, mana yang sebenarnya menjadi realita nyata dari pelaku? Apakah yang makan cantik? Ataukah yang makan di rumah makan pinggir jalan? Dalam hal ini realita yang sebenarnya sudah runtuh. Hal ini digantikan oleh simulasi yang membuat realitas menjadi kabur.
Makan cantik dianggap representasi kelas atas dan makan dipinggir jalan merupakan representasi kelas bawah. Oleh karna itu telah terjadi pengaburan kelas dimana tidak adanya kejelasan dari status kelas yang dimunculkan di sosial media. Social media saat ini tidaklah lagi menampilkan realitas yang sebenarnya, namun menampilkan hiperealitas. Yang dilakukan oleh social media saat ini adalah simulasi, manipulasi, rekayasa dan mengubah bentuknya sendiri menjadi pesan itu sendiri (Kushendrawati, 2006: 146)

Makan cantik merupakan sebuah hiperealitas dimulai dengan gejala timbulnya realiatas-realitas buatan yang pada akhirnya menjadi lebih rill daripada yang rill. Kegiatan makan cantik membuat orang berfikir bahwa orang yang melakukan hal tersebut adalah orang yang memiliki kemampuan ekonomi yang cukup. Padahal untuk bisa mewujudkan hal tersebut pelaku harus melakukan usahausaha terlebih dahulu. Realitasyang diunggah oleh pelaku di social media akan memberikan gambaran bahwa pelaku merupakan kelas atas. Social media memudahkan masyarakat untuk membuat simbol bersama tanpa harus bertemu ataupun berinteraksi, bahkan tidak kenal sekalipun. Namun simulasi ini tidak dapat terwujud jika pelaku makan cantik tidak memotret-motret kegiatannya tersebut kemudian mengunggahnya di sosial media.

Pelaku makan cantik melakukan beberapa simulasi dalam membentuk realitas yang ingin dibangun. Pertama pelaku makan cantik harus memotret makanan semenarik mungkin. Karena ada anggapan bahwa mereka yang mengkonsumsi makanan estetik akan dianggap sebagai masyarakat kelas atas (Raditya, Michael HB. 2014; 158). Sehingga pelaku makan cantik harus bisa menunjukan aksen keunikan ataupun kemewahan dari makanan yang pesan. Kemudian simulasi lainnya dilakukan adalah pelaku makan cantik memotret dirinya berada pada restoran tersebut. Simulasi ini dibalut dengan penggunaan pakaian yang menyesuaikan dengan tema dari restoran tersebut.

Jika restoran tersebut merupakan restoran fine dining biasanya pelaku menyesuaikan diri dengan menggunakan dress 
ataupun high heels untuk perempuan ataupun kemeja dan sepatu untuk laki-laki agar terlihat lebih rapih. Oleh karena itu sebelum datang ke restoran, pelaku harus memilih restoran mana yang akan ia kunjungi agar pelaku bisa menyesuaikan dengan pakaian yang ia kenakan saat itu. Penggunaan pakaian yang rapih, dan mengikuti mode yang ada akan menggambarkan bahwa pelaku adalah orang yang selalu mengikuti tren. Tentunya tren berpakaian yang menjadi pijakan adalah tren berpakaian kelas atas, ataupun artisartis tertentu baik berasal dari dalam negri maupun luar negeri.

Pelaku makan cantik harus mempersiapkan simulasi tersebut sebaik mungkin agar apa yang ia ingin gambarkan di sosial media dapat menunjukan bahwa ia berada pada kelas sosial atas, sesuai dengan apa yang ia diinginkan. Proses manipulasi menjadikan realitas buatan tersebut terputus hubungan dengan realitas aslinya.

Simulasi yang dihadirkan di sosial media yang bertujuan untuk menampilkan kelas tidak hanya dilakukan dalam satu waktu. Namun harus dilakukan berulang-ulang agar orang lain menganggap hal tersebut merupakanbagiandarigaya hiduppelaku. Hal tersebut tidak terlepas karena makan cantik dianggap sebagai gaya hidup masyarakat kelas atas. Simulasi yang dilakukan berulangulang dapat memunculkan reealitas yang bukan realitas.

Realitas yang dihadirkan di sosial media menjadi acuan utama, bahkan lebih menjadi realitas itu sendiri. Sedangkan realitas utamanya perlahan-lahan hilang ataupun blur. Masyarakat seolah-olah meyakini bahwa yang nyata adalah makan cantik itu lah yang menjadi gambaran kehidupan si pelaku dalam sosial medianya. Sehingga apa yang tidak ditampilkan di social media bukanlah realitas dari pelaku. Sehingga muncul pertanyaan bahwa sejauh mana makan cantik menyembunyikan fakta bahwa yang nyata (makan di pinggir jalan sebagai representasi kelas bawah) tidak lagi nyata? Sehingga dapat dikatakan bahwa makan cantikitusendirisebenarnyaadalahfenomena hiperealitas. Di satu sisi makan cantik ada untuk merepresentasikan kehidupan pelaku makan cantik. Namun disisi yang lain, kelas sosial yang ingin ditampilkan tersebut menjadi hiperealitas. Oleh sebab itu dapat disimpulkan bahwa makan cantik tidak lebih dari kegiatan permanipulasian dan penipuan yang dilakukan lewat proses simulasi.

\section{SIMPULAN}

Fenomena makan cantik terlah menjadi bagian dari gaya hidup masyarakat perkotaan saat ini. Dalam melakukan makan cantik, memberitahukan kepada masyarakat secara luas sangat perlu untuk dilakukan. Pelaku makan cantik menggunakan social media untuk menyiar-nyiarkan kegiatan. Karena makan cantik dan social media merupakan satu kesatuan yang utuh. Hal ini dianggap karena social media merupakan ruang terbaik terbentuknya hiperrealitas. Hiperrealitas dalam social media dapat terwujud karena soeial media dapat merepresentasikan hiperrealitas menjadi realitas palsu. Dalam pelaksanaanya makan cantik dianggap dapat merepresentasikan kelas atas sebagai pembentuk identitas. Makan cantik menjadi sebuah gambaran atau citra yang melambangkan eksistensi dan kelas sosial masyarakat.

Oleh sebab itu simulasi menjadi hal yang penting dalam pembentukan hiperrealitas. Dalam hal ini simulasi dimulai sejak pemilihan restoranyang memang menyajikan interior ruangan, peyajian makanan yang menarik. Adapun simulasi dilakukan dengan memotret foto makanan sebaik mungkin ataupun ruangan yang semenarik mungkin serta penggunaan caption yang eye catching agar orang lain tertarik untuk datang ke tempat tesebut. Makan cantik itu sendiri dikonstruksi oleh social media, bahkan apa yang diunggah oleh pelaku di sosial media juga secara tidak langsung telah mengkontruksi orang lain. Baik yang gemar makan cantik maupun tidak.

Namun pada kenyataannya makan cantik yang diunggah di dalam social media merupakan suatu hal yang berbeda dari fakta yang ada. Karena terdapat perbedaan 
kondisi pelaku pada apa yang diunggah dengan kondisi yang nyata. Simulasi yang dilakukan oleh pelaku makan cantik di sosial media menampilkan kondisi kelas sosial atas, namun ternyata pelaku makan cantik bukan dari kelas sosial tersebut. Sehingga dapat dikatakan bahwa realita yang sebenarnya sudah runtuh. Hal ini digantikan oleh simulasi yang membuat realitas menjadi kabur. Hiperrealita menyebabkan terjadinya pengaburan kelas yang pada akhirnya memberikan dampak adanya ketidak jelasan dari status kelas sosial seseorang yang di tampilkan pada social media.

\section{DAFTAR PUSTAKA}

Alfian, Pandu Rizki. 2014. "Musik Dangdut Koplo Menurut Perspektif Jean Baudrillard”. Skripsi tidak diterbitkan, Fakultas Ushuludin dan Filsafat Universitas Islam Negeri Sunan Ampel.

Barker, Chris. (2011) Cultural Studies: Teori dan praktik (terjemahan: Tim Kunci Cultural Studies Centre). Yogyakarta: Bentang (PT Bentang Pustaka)

Denzin. Norman K. 1986. "Post Moderns Social Theory". Jurnal Sociological Theory, Vol. 4, Number. 2 (Autumn, 1986), 194-204

Djaafara, Febiana. 1994. "Kegiatan Makan di Luar Rumah Pada Masyarakat Perkotaan: Studi Kasus Fungsi Institusi Makan Bagi Para Pekerja pada Kawasan Sudirman - Thamrin di Jakarta." Skripsi tidak diterbitkan, Fakultas Ilmu Sosial dan Ilmu Politik Universitas Indonesia.

Irfani, Bunga. 2014. "Eating Out Sebagai Gaya Hidup Dan Konsumerisme Di Nanamia Pizzeria dan Il Mondo Yogyakarta." Tesis tidak diterbitkan, Program Kajian Budaya dan Media Universitas Gajah Mada.

Jean Baudrillard. 1981. Simulacra and Simulation. United State of Amerika: The University of Michigan Press. 1983. Simulations. Massachusetts: The MIT Press.

Kushendrawati, Selu Margaretha. 2006. "Hiperrealitas Dalam Media Massa: Suatu Kajian Filsafat Jean Baudrillard." Disertasi tidak diterbitkan, Fakultas Ilmu Pengetahuan Budaya Universitas Indonesia.

Maslow, Abraham H. 1987. Motivation and Personality. NY: Addison-Wesley.

Meliono, V Irmayanti dan Boediono. 2004. "Dimensi Etis Terhadap Budaya Makan dan Dampaknya pada Masyarakat". Jurnal Makara, Sosial Humaniora, Vol. 8, Nomor. 2, Agustus: 65-70. 
Murcott, Anne. 1988. "Sociological and Social Antrhopological Approaches to Food and Eating". Jurnal World Review of Nutrition and Dietetics. Vol. 55

Murwani, Endah. 2015. “'Eating Out' Makanan Khas Daerah: Komoditas Gaya Hidup Masyarakat Urban.” Jurnal Universitas Multimedia Nusantara.

Neuman. W Lawrence. 2006. Social Research Methods Sixth Edition. Boston: Allyn and Bacon.

Raditya, Michael HB. 2014. "Antara Rasa dan Estetika Komodifikasi Nilai Konsumsi Pada Pangan Sebagai Wujud Eksistensi”. Jurnal Kawistara. Vol. 4: 111- 224.

Wawancara dengan MT, 27 Oktober 2015.

Wawancara dengan GO, 8 November 2016. 